\author{
PATRYk Brambert \\ Uniwersytet Jana Kochanowskiego w Kielcach, Polska - Jan Kochanowski University in Kielce, Poland \\ IWONA KINIORSKA \\ Uniwersytet Jana Kochanowskiego w Kielcach, Polska - Jan Kochanowski University in Kielce, Poland
}

\title{
Znaczenie funduszy unijnych dla rozwoju przedsiębiorczości i innowacyjności regionu świętokrzyskiego. Przykład klastra Grono Targowe Kielce
}

\section{The Importance of the EU Funds for the Development of Entrepreneurship and Innovation in the Świętokrzyskie Region. An Example of the Grono Targowe Kielce Cluster}

\begin{abstract}
Streszczenie: Klastry pełnią istotną funkcję w rozwoju procesów przedsiębiorczości, opartych na innowacyjności. Jest to problematyka szeroko dyskutowana w literaturze zagranicznej, jednak wymaga $\mathrm{w}$ dalszym ciągu wnikliwych analiz na gruncie krajowym. Przedmiotem badań opisywanych w artykule było Grono Targowe Kielce - największy i najstarszy klaster w województwie świętokrzyskim. W pracy wykazano znaczenie wpływu funduszy strukturalnych pozyskiwanych przez członków klastra na ukierunkowywanie charakteru rozwoju regionu świętokrzyskiego. Zanalizowano strukturę finansowania projektów zrealizowanych przez podmioty gospodarcze należące do wybranego klastra, a także wyłącznie przez koordynatora zrzeszenia. Zakres czasowy objął lata 2005-2013. Wykazano zwłaszcza realizacje, które dotyczyły województwa świętokrzyskiego, czyli zostały przeznaczone bezpośrednio bądź pośrednio na jego rozwój, z podziałem na poprawę przedsiębiorczości, innowacyjności i konkurencyjności. Wyniki badań pozwoliły wskazać, iż środki pomocowe otrzymane przez klaster i jego członków przyczyniły się do rozwoju województwa w rozpatrywanych płaszczyznach. Większość projektów zrealizowano podczas członkostwa w klastrze, a objęły one głównie kapitał ludzki. Klaster jako beneficjent brał udział we wsparciu potencjału dydaktycznego ośrodka akademickiego dla potrzeb rynku pracy, a także w promocji gospodarczej i inwestycyjnej regionu.
\end{abstract}

\begin{abstract}
Clusters play an important role in the development of entrepreneurial processes based on innovation. This issue is widely discussed in professional literature abroad; however, it still requires thorough analyses on the national level. The subject of the study is Grono Targowe Kielce - the largest and oldest cluster in Świętokrzyskie Voivodeship. The paper shows the significance of structural funds obtained by the cluster members for shaping the development of the Świętokrzyskie region. The analysis focuses on financing structure of projects implemented by business entities belonging to the cluster in question, including its coordinator. The study refers to the period of 2005-2013. It describes implemen-
\end{abstract}


ted projects concerning Świętokrzyskie Voivodeship, i.e. those which were directly or indirectly used for its development, broken down into: improvements of entrepreneurship, innovation, and competitiveness. The results show that subsidies obtained by the cluster and its members contributed to the development of the voivodeship in various aspects. Most projects were implemented during cluster membership and mainly referred to human capital. The cluster as the beneficiary supported the didactic potential of the academic centre focused on the needs of the labour market. Moreover, it participated in economic and investment promotion of the region in question.

Słowa kluczowe: fundusze unijne; Grono Targowe Kielce; innowacyjność; klaster; przedsiębiorczość

Keywords: cluster; entrepreneurship; EU funds; Grono Targowe Kielce; innovation

Otrzymano: 27 maja 2019

Received: 27 May 2019

Zaakceptowano: 12 sierpnia 2019

Accepted: 12 August 2019

\section{Sugerowana cytacja/Suggested citation:}

Brambert P., Kiniorska I. (2019). Znaczenie funduszy unijnych dla rozwoju przedsiębiorczości i innowacyjności regionu świętokrzyskiego. Przykład klastra Grono Targowe Kielce. Przedsiębiorczość - Edukacja, [Entrepreneurship - Education], 15(2), 227-247. doi: 10.24917/20833296.152.16

\section{Wstęp}

Przedsiębiorczość traktowana jest jako jeden z elementarnych czynników wzrostu społeczno-gospodarczego układów każdej skali przestrzennej (Brdulak, Kulikowski, 2004; Churski, 2014; Kamińska, 2006; Kamińska, Heffner, 2012; Kuciński, 1999; Płaziak, Rachwał, 2015; Zioło, 2016). Mówiąc o przedsiębiorczości, często wskazuje się na innowacyjność. Innowacyjność - jako cecha podmiotów gospodarczych lub gospodarek oznacza zdolność do tworzenia lub pozyskiwania nowych bądź ulepszonych produktów, procesów, rynków i metod organizacji, wiążącą się z aktywnym angażowaniem się w procesy innowacyjne i podejmowanie działań w tym kierunku; oznacza też zaangażowanie w zdobywanie zasobów i umiejętności niezbędnych do uczestniczenia w tych procesach (Matusiak, 2011). Fundamentem każdej organizacji są ludzie, dlatego należy odnieść się w tym miejscu do pojęcia zdolności. Jest ono ściśle związane z indywidualnymi różnicami osiągnięć międzyludzkich. Zdolność to zatem układ warunków wewnętrznych danej jednostki, wyznaczający poziom oraz jakość jej osiągnięć w wykonywanej przez nią działalności (Zastempowski, 2019). Zbiór tych zdolności to budulec potencjału całej organizacji. Zjawisko zdolności innowacyjnej było głównym punktem dyskusji w wielu badaniach dotyczących budowania i utrzymywania przewagi konkurencyjnej przedsiębiorstw oraz wdrażania ich strategii (m.in.: Altuntas, Dereli, Kusiak, 2016; Alves i in., 2017; Ramanathan B., Ramanathan U., Bentley., 2018; Stawasz, 2013; Zastempowski, 2019).

Rozważania naukowe nad innowacyjnością mają niedługą historię, gdyż pojawiły się w latach 60. XX w. Początkowo dotyczyły konceptualizacji pojęcia innowacji i wpływu czynników otoczenia na sposób funkcjonowania organizacji (m.in.: Ross, 1973; Schumpeter, 1960). W latach 80. i 90. XX w. szereg publikacji poświęcono problematyce projektowania podmiotów innowacyjnych (m.in.: Anderson, Tushman, 1990; Kline, 1985), a obecnie najwięcej miejsca zajmuje tematyka innowacji jako narzędzia osiągania 
korzystnych wyników przez przedsiębiorstwo (m.in.: Felin, Powell, 2016; Jasińska-Bilczak, 2017; Varis, Littunen, 2010).

Wzmacnianie innowacyjności to priorytet Unii Europejskiej (UE) w wydatkowaniu środków. Potwierdzają to liczne badania dotyczące chociażby Polski. Podkreśla się w nich najczęściej, że projekty UE koncentrowały się na poprawie stanu przedsiębiorczości oraz na wzroście możliwości zdobywania wiedzy i jej rozpowszechniania, zgodnie z celami gospodarki opartej na wiedzy. Badaczy niepokoił fakt pogłębiania się dysproporcji rozwoju społeczno-gospodarczego, co tłumaczono różnym stopniem wykorzystania instrumentów polityki spójności (m.in.: Churski, 2014; Kiniorska, Pałka, Brambert, 2015; Jaki, Rojek, 2018; Piątkowski, 2010). W obecnych realiach konkurencyjność polskiej gospodarki będzie uzależniona od podwyższenia poziomu jej innowacyjności, zgodnie z polityką państwa i UE. Dokumenty strategiczne za podstawowy cel rozwoju przedsiębiorstw wyznaczają wzrost ich innowacyjności, przedsiębiorczości i efektywnej działalności (Jasińska-Bilczak, 2017).

Niezmiernie istotną rolę $\mathrm{w}$ rozwoju procesów przedsiębiorczości, opartych na innowacyjności, odgrywają działania w ramach klastrów w ujęciu porterowskim (OECD, 1997; Porter, 2000; Szultka, 2004). Podmioty gospodarcze, które je tworzą, cechują się wysokim stopniem specjalizacji oraz wzajemnym uzupełnianiem się dóbr i usług. Dzięki temu zachodzi szybki proces tworzenia wiedzy i jej dyfuzji, co ma przełożenie na zwiększenie konkurencyjności.

Problematyka klastrów oraz rozwoju regionalnego z ich udziałem została poruszona w obszernej zagranicznej literaturze przedmiotu (m.in.: Breschi, Malerba, 2007; Delgado i in., 2012; Enright, 1996). Od początku XXI w. zyskuje na popularności w badaniach krajowych (m.in.: Bojar, 2006; Brambert, 2016, 2018; Brodzicki, Kuczewska, 2012; Kowalski, 2013; Micek, 2008; Nowak, Brambert, 2014; Olejniczak, Dziemianowicz, 2003; Olesiński, 2008).

\section{Założenia metodologiczne}

Motywem do podjęcia badań było wypełnienie luki w piśmiennictwie geograficznym na temat roli powiązań sieciowych między podmiotami gospodarczymi dla rozwoju przedsiębiorczości i innowacyjności, na podstawie studium przypadku, czyli największego i najstarszego na terenie województwa świętokrzyskiego klastra - Grona Targowego Kielce (GTK).

Celem opracowania było wykazanie znaczenia pozyskanych przez członków klastra funduszy UE na rzecz rozwoju regionu świętokrzyskiego. Podjęto próbę odpowiedzi na następujące pytania badawcze: 1. Czy pozyskiwane przez klaster i jego członków fundusze UE wpływają na wzrost przedsiębiorczości, innowacyjności i konkurencyjności regionu? 2. W jakim stopniu specjalizacja branżowa podmiotów klastra rzutuje na wysokość zdobytych środków?

Przedmiot badań to grupa 86 podmiotów gospodarczych i instytucji zrzeszonych w ramach izby gospodarczej, których 84 siedziby zlokalizowano na terenie woj. świętokrzyskiego (16 gmin), przy czym ponad 70\% z nich - w Kielcach (region zakorzenienia). Wśród 134 polskich klastrów GTK jest ważną i specyficzną strukturą, gdyż stanowi jedyne zrzeszenie realizujące działania związane z branżą targowo-wystawienniczą (PARP, 2016). Koncepcja powstania zrodziła się po dostrzeżeniu ogromnej roli ośrodka wystawienniczego Targi 
Kielce $\mathrm{w}$ stymulowaniu rozwoju gospodarczego województwa świętokrzyskiego (Urząd Miasta Kielce, 2015). Charakter jego działalności i skala oddziaływania usług umożliwiają generowanie współpracy przedsiębiorstw $\mathrm{z}$ wielu branż. Z tego względu pod koniec $2007 \mathrm{r}$. sformalizowano istnienie klastra GTK w formie samorządu gospodarczego, którego członkowie reprezentowali 6 branż. Wokół Targów Kielce utworzył się łańcuch kooperacji dla przedsiębiorstw doradczych (21) i szkoleniowych (11), co m.in. pomaga sprawnie promować i reklamować (13) marki, w tym usługi hotelarsko-gastronomiczne (20), transportowe, a także zasoby i walory turystyczne (19) (Brambert, 2016).

Ukształtowany dotychczas profil klastra GTK cechuje m.in.:

- dominacja podmiotów należących do branży doradztwa biznesowego i hotelarsko-gastronomicznej,

- przewaga lokalizacji siedzib w miastach, zwłaszcza w Kielcach,

- zasięg regionalny, dzięki podmiotom zlokalizowanym w województwie, wraz z siecią jednostek lokalnych, które sprzyjają rozbudowywaniu sieci relacji biznesowych,

- znaczący udział podmiotów sekcji wachlarza usług profesjonalnych, naukowych, technicznych, wspierających i edukacyjnych (V sektor ekonomiczny),

- dominacja mikroprzedsiębiorstw,

- posiadanie potencjału wzrostowego o charakterze otwartym (Nowak, Brambert, 2014).

Klaster GTK w aktualnej polityce i strategii rozwoju regionalnego, opartej na unijnej koncepcji inteligentnej specjalizacji, uosabia targowo-kongresową specjalizację horyzontalną województwa świętokrzyskiego (Zarząd Województwa Świętokrzyskiego, 2014). Wiąże się to z możliwościami pozyskiwania specjalnych środków finansowych, które pochodzą z budżetu państwa lub ze źródeł pomocowych UE. Zajęto się więc problemem finansowego wsparcia rozwoju jednostek składowych tego jednego z kluczowych pól koncentracji działalności. Punktem wyjścia była charakterystyka absorpcji środków z UE, zainwestowanych precyzyjnie w obszary, które rozwijając się same, mogą powodować rozwój innych zależnych organizacji (Churski, 2014). Wspomagają one zarazem potencjał całej gospodarki i województwa świętokrzyskiego, który musi być skupiony szczególnie na rozwoju innowacji i postępie technologicznym.

W świetle przedstawionych przesłanek dokonano analizy struktury środków unijnych pozyskanych przez podmioty gospodarcze należące do klastra GTK (stan na 2013 r. $^{1}$ ), a także uzyskanych wyłącznie przez koordynatora zrzeszenia - Izbę Gospodarczą GTK. Zakres czasowy objął lata 2005-2013. Podzielono go też na 2 okresy: przed powstaniem klastra (2005-2007) i w czasie rozwoju klastra (2008-2013). Zbadano realizacje wg chronologii umów współfinansowania zawartych w danym roku kalendarzowym. Porównano przy tym sytuację niezależną z sytuacją zależną od momentu przystąpienia podmiotu (beneficjenta) do klastra. Dane pochodziły głównie z zasobów Ministerstwa Rozwoju (MR), tj. serwisów internetowych na temat środków unijnych w Polsce - Mapa Dotacji UE i Portal Funduszy Europejskich na lata 2007-2013. Wyodrębniono szczególnie te realizacje, które objęły zasięgiem terytorialnym województwo świętokrzyskie, czyli zostały przeznaczone bezpośrednio bądź pośrednio na jego rozwój. Zaglomerowane projekty

${ }^{1}$ Dobór górnej granicy zakresu czasowego uwarunkowany był osiągniętym etapem w cyklu życia klastra (faza wzrostu), z maksymalną liczebnością członków, która jak dotąd znacznie się nie zmieniła (89 podmiotów w 2019 r.) oraz możliwością ujęcia głównie zakończonej drugiej perspektywy finansowej, tj. na lata 2007-2013. 
zawierają realizacje wypełniające założenia programów operacyjnych z 3 funduszy: Europejskiego Funduszu Rozwoju Regionalnego (EFRR), Europejskiego Funduszu Społecznego (EFS), Europejskiego Funduszu Orientacji i Gwarancji Rolnej (EFOiGR). W realizacji celu zwrócono uwagę na fundusze UE (na lata 2008-2013) przeznaczone przez podmioty klastra na rzecz przedsiębiorczości, innowacyjności i konkurencyjności w regionie wg działań i programów operacyjnych. Efektem było wyznaczenie 3 kierunków rozwoju. Badanie miało charakter ilościowy, oparty na analizie zmiennych za pomocą statystyk opisowych, tzn. miar występowania (liczebność, odsetek) i położenia (średnia).

W strukturze ilościowej uwzględniono także partnerstwa członków klastra w postaci wspólnych projektów. Opracowano dzięki temu mapę współpracy sieciowej. Podstawą do jej stworzenia były unijne projekty partnerskie, w których rolę liderów mieli członkowie klastra GTK, zaś partnerów - podmioty z lub spoza klastra. W wektorze o zwrocie lider - partner (węzły sieci) bardzo ważnym elementem charakteru relacji, który został zobrazowany za pomocą grubości wektora, jest siła współpracy wg łącznej wartości zrealizowanych projektów. W węzłach umiejscowienia liderów zilustrowano łączną wartość unijnych projektów partnerskich zainicjowanych przez członków klastra.

\section{Wyniki badań}

Wśród badanych członków klastra, którzy pozyskiwali w latach 2005-2013 środki unijne, było 26 (30\%) podmiotów (tabela 1). Najwięcej, tj. 15, podmiotów sięgnęło po finansowanie w 2010 r. Do tegoż roku ich liczba wzrastała od poziomu 4 przedsiębiorstw, a po tym czasie aktywność ta spadła o połowę. Liczba projektów była maksymalna również w 2010 r., a do tego momentu wykazała trend rosnący. Potem stan projektów nie uległ diametralnemu zmniejszeniu, do 21 w 2013 r. Łącznie uzyskano dofinansowanie dla 154 wniosków. Największy odsetek projektów było świadczonych z EFS - stanowiły one 83\% (128) ogółu. Co piąta taka umowa została zawarta w 2011 r. Środki pochodziły z Programu Operacyjnego Kapitał Ludzki (PO KL). Ten program był najważniejszy w strukturze i objął 114 projektów (75\% realizacji). W kontekście rozwoju innowacji na marginesie znalazły się projekty z PO Innowacyjna Gospodarka (IG). Przedsięwzięcia w przeważającej większości obejmowały swym zasięgiem przestrzennym poszczególne województwa (137, tj. 89\%). Okres programowania 2007-2013 cechował się w kraju naciskiem na projekty regionalne, co widać i w tym ujęciu. Od 2008 r. podmioty klastra wykonały średnio 21 projektów, które dotyczyły wsparcia w granicach regionów.

Wartość ogółem projektów opiewała na 469,1 mln zł, z czego aż 46\% (215,5 mln zł) podmioty pozyskały w 2009 r. W pozostałych latach widać duże zróżnicowanie efektywności projektów, co uwidacznia się w diametralnie niższych kwotach.

W strukturze funduszy UE, które pozyskały podmioty z GTK w latach 2005-2013, 65\% (100) ogółu projektów obejmowało przestrzeń województwa świętokrzyskiego. Ich tematyka zakładała polepszenie uwarunkowań społeczno-gospodarczych lub infrastrukturalnych przez konkretne działania beneficjentów w zakresie prowadzonych przez nich działalności gospodarczych, dlatego określono je jako fundusze dla rozwoju regionu świętokrzyskiego (tabela 2). W każdym roku, z wyjątkiem 2013 r., miał miejsce przeważający udział liczby realizacji. Tylko w 2006 r. i 2007 r. były to wszystkie projekty. W latach 2009-2011 zawarto najwięcej (na poziomie 19) umów dla rozwoju województwa. Z drugiej strony w latach 2008-2013 dostrzeżono trend spadkowy proporcji przedsięwzięć regionalnych. 
Tabela 1. Struktura funduszy UE pozyskanych przez podmioty klastra GTK w latach 2005-2013, niezależnie od czasu przystąpienia do klastra

\begin{tabular}{|c|c|c|c|c|c|c|c|c|c|c|c|c|}
\hline \multirow{2}{*}{\multicolumn{3}{|c|}{ Wyszczególnienie }} & \multicolumn{9}{|c|}{ Lata } & \multirow{2}{*}{ 苛 } \\
\hline & & & 200 & 2006 & 2007 & 2008 & 2009 & 2010 & 2011 & 2012 & 2013 & \\
\hline \multicolumn{3}{|c|}{ Liczba podmiotów } & 4 & 3 & 3 & 7 & 7 & 15 & 8 & 8 & 6 & 26 \\
\hline \multirow{15}{*}{ 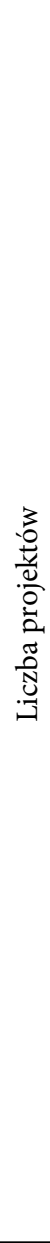 } & \multicolumn{2}{|c|}{ Ogółem } & 7 & 4 & 3 & 15 & 25 & 29 & 29 & 21 & 21 & 154 \\
\hline & \multirow{3}{*}{ 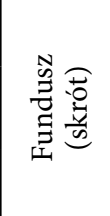 } & EFRR & 0 & 0 & 3 & 2 & 2 & 11 & 3 & 2 & 2 & 25 \\
\hline & & EFS & 6 & 4 & 0 & 13 & 23 & 18 & 26 & 19 & 19 & 128 \\
\hline & & EFOiGR & 1 & 0 & 0 & 0 & 0 & 0 & 0 & 0 & 0 & 1 \\
\hline & & ZPORR & 3 & 3 & 1 & 0 & 5 & 0 & 0 & 0 & 0 & 12 \\
\hline & & RZL & 3 & 1 & 0 & 0 & 0 & 0 & 0 & 0 & 0 & 4 \\
\hline & & WKP & 0 & 0 & 2 & 0 & 0 & 0 & 0 & 0 & 0 & 2 \\
\hline & & KL & 0 & 0 & 0 & 14 & 18 & 18 & 26 & 19 & 19 & 114 \\
\hline & & IG & 0 & 0 & 0 & 0 & 0 & 2 & 1 & 1 & 0 & 4 \\
\hline & & RPW & 0 & 0 & 0 & 0 & 1 & 1 & 0 & 1 & 0 & 3 \\
\hline & & RPOWŚ & 0 & 0 & 0 & 1 & 1 & 8 & 1 & 0 & 2 & 13 \\
\hline & & RPOWM & 0 & 0 & 0 & 0 & 0 & 0 & 1 & 0 & 0 & 1 \\
\hline & & inne & 1 & 0 & 0 & 0 & 0 & 0 & 0 & 0 & 0 & 1 \\
\hline & \multirow{2}{*}{ 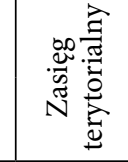 } & regiony & 5 & 4 & 3 & 12 & 22 & 28 & 25 & 19 & 19 & 137 \\
\hline & & kraj & 2 & 0 & 0 & 3 & 3 & 1 & 4 & 2 & 2 & 17 \\
\hline \multirow{4}{*}{ 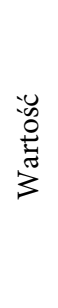 } & Ogółem & mln zł & 15,1 & 4,5 & 1,6 & 19,2 & 215,5 & 116,3 & 53,4 & 18,4 & 25,2 & 469,1 \\
\hline & \multirow{3}{*}{ 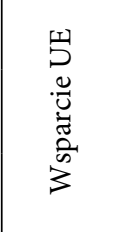 } & $\mathrm{mln} \mathrm{zł}$ & 9,6 & 3,3 & 0,5 & 13,4 & 79,6 & 84,3 & 35,9 & 14,6 & 18,8 & 260,0 \\
\hline & & $\begin{array}{l}\% \\
\text { ogółem }\end{array}$ & 63,4 & 73,7 & 30,1 & 69,9 & 36,9 & 72,5 & 67,3 & 79,3 & 74,7 & 55,4 \\
\hline & & $\begin{array}{l}\text { średni } \\
\text { udział }\end{array}$ & 70,7 & 73,6 & 41,5 & 75,9 & 73,8 & 58,1 & 76,4 & 79,1 & 66,8 & 68,4 \\
\hline
\end{tabular}

Źródło: opracowanie własne na podstawie danych Ministerstwa Rozwoju (2015) 
Tabela 2. Struktura funduszy UE pozyskanych przez podmioty klastra GTK dla rozwoju regionu świętokrzyskiego w latach 2005-2013, niezależnie od czasu przystąpienia do klastra

\begin{tabular}{|c|c|c|c|c|c|c|c|c|c|c|c|}
\hline \multirow{2}{*}{\multicolumn{2}{|c|}{ Wyszczególnienie }} & \multicolumn{9}{|c|}{ Lata } & \multirow{2}{*}{ Ogółem } \\
\hline & & 2005 & 2006 & 2007 & 2008 & 2009 & 2010 & 2011 & 2012 & 2013 & \\
\hline Liczl & podmiotów & 4 & 3 & 3 & 7 & 7 & 15 & 8 & 8 & 6 & 26 \\
\hline \multicolumn{12}{|c|}{ Projekty dla województwa świętokrzyskiego } \\
\hline \multicolumn{2}{|r|}{ Liczba } & 5 & 4 & 3 & 11 & 18 & 19 & 18 & 14 & 8 & 100 \\
\hline \multicolumn{2}{|r|}{$\%$} & 71,4 & 100,0 & 100,0 & 73,3 & 72,0 & 65,5 & 62,1 & 66,7 & 38,1 & 64,9 \\
\hline \multirow{2}{*}{ 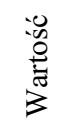 } & $\operatorname{mln} \mathrm{z} ł$ & 4,3 & 4,5 & 1,6 & 5,7 & 200,8 & 107,1 & 30,1 & 13,6 & 13,4 & 381,1 \\
\hline & \% ogółem & 28,4 & 100,0 & 100,0 & 29,6 & 93,2 & 92,1 & 56,4 & 74,1 & 53,1 & 81,2 \\
\hline \multirow{2}{*}{$\begin{array}{l}\stackrel{0}{0} \\
0 \\
0 \\
0 \\
0 \\
0\end{array}$} & $\mathrm{mln} \mathrm{z} \mathfrak{}$ & 3,1 & 3,3 & 0,5 & 4,0 & 69,3 & 77,1 & 21,8 & 10,8 & 8,8 & 198,6 \\
\hline & $\%$ dotacji & 32,7 & 100,0 & 100,0 & 29,8 & 87,0 & 91,4 & 60,6 & 73,9 & 47,0 & 76,4 \\
\hline \multicolumn{12}{|c|}{ Projekty pozostale } \\
\hline \multicolumn{2}{|r|}{ Liczba } & 2 & 0 & 0 & 4 & 7 & 10 & 11 & 7 & 13 & 54 \\
\hline \multicolumn{2}{|r|}{$\%$} & 28,6 & 0,0 & 0,0 & 26,7 & 28,0 & 34,5 & 37,9 & 33,3 & 61,9 & 35,1 \\
\hline \multirow{2}{*}{ 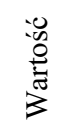 } & $\mathrm{mln} \mathrm{zł}$ & 10,8 & 0,0 & 0,0 & 13,5 & 14,7 & 9,2 & 23,3 & 4,8 & 11,8 & 88,1 \\
\hline & \% ogółem & 71,6 & 0,0 & 0,0 & 70,4 & 6,8 & 7,9 & 43,6 & 25,9 & 46,9 & 18,8 \\
\hline \multirow{2}{*}{ 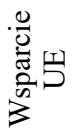 } & $\mathrm{mln} \mathrm{z} \mathfrak{}$ & 6,4 & 0,0 & 0,0 & 9,4 & 10,3 & 7,3 & 14,2 & 3,8 & 10,0 & 61,4 \\
\hline & $\%$ dotacji & 67,3 & 0,0 & 0,0 & 70,2 & 13,0 & 8,6 & 39,4 & 26,1 & 53,0 & 23,6 \\
\hline
\end{tabular}

Źródło: opracowanie własne na podstawie danych MR (2015)

Wartość omawianych projektów stanowiła 81,2\% łącznych środków, osiągając $381,1 \mathrm{mln}$ zł, z czego ponad 50\% - 200,8 mln zł - zostało zaabsorbowanych w 2009 r. To prawie wszystkie środki pozyskane przez przedsiębiorstwa w 2009 r. Mimo że liczba projektów na cele regionalne zmniejszała się w latach 2009-2013, to poziom wartości wydatkowanych funduszy był dominujący w strukturze. Analogicznie do sumy ogółu projektów w dziewięcioleciu, najsilniej dotowane przez UE projekty pochodziły z $2009 \mathrm{r}$. i 2010 r. - odpowiednio 69,3 mln zł (87\% dotacji) i 77,1 mln zł (91,4\%). Złożyły się one na ponad 75\% ogółu dofinansowań, tj. niemal 198,6 mln zł przypisanych województwu świętokrzyskiemu.

Po uwzględnieniu podziału charakteryzowanej struktury funduszy pomocowych dla przedsiębiorstw klastra GTK na czas przed jego powstaniem i podczas funkcjonowania, niezależnie od czasu przystąpienia (tabela 3), stwierdzono prawidłowości. Największą aktywność podmioty przejawiały drugim okresie, ponieważ projekty wykazało wtedy 23 członków. Wypadkową tego była znaczna przewaga realizacji, w liczbie 140 (91\% 
Tabela 3. Struktura funduszy UE pozyskanych przez podmioty klastra GTK w latach 2005-2007 i 2008-2013, niezależnie od czasu przystąpienia do klastra

\begin{tabular}{|c|c|c|c|c|c|c|c|}
\hline & \multicolumn{2}{|c|}{ Wyszczególnienie } & $\begin{array}{c}\text { Lata } \\
2005- \\
2007 \\
\end{array}$ & $\begin{array}{c}\% \\
\text { ogółu }\end{array}$ & $\begin{array}{c}\text { Lata } \\
2008- \\
2013 \\
\end{array}$ & $\begin{array}{c}\% \\
\text { ogółu }\end{array}$ & Ogółem \\
\hline & \multicolumn{2}{|c|}{ Liczba podmiotów } & 7 & 26,9 & 23 & 88,5 & 26 \\
\hline \multirow{15}{*}{ 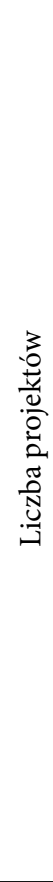 } & \multicolumn{2}{|c|}{ Ogółem } & 14 & 9,1 & 140 & 90,9 & 154 \\
\hline & \multirow{3}{*}{$\begin{array}{l}\text { Fundusz } \\
\text { (skrót) }\end{array}$} & EFRR & 3 & 12,0 & 22 & 88,0 & 25 \\
\hline & & EFS & 10 & 7,8 & 118 & 92,2 & 128 \\
\hline & & EFOiGR & 1 & 100,0 & 0 & 0,0 & 1 \\
\hline & \multirow{9}{*}{$\begin{array}{c}\text { Program } \\
\text { Operacyjny } \\
\text { (skrót) }\end{array}$} & ZPORR & 7 & 58,3 & 5 & 41,7 & 12 \\
\hline & & RZL & 4 & 100,0 & 0 & 0,0 & 4 \\
\hline & & WKP & 2 & 100,0 & 0 & 0,0 & 2 \\
\hline & & $\mathrm{KL}$ & 0 & 0,0 & 114 & 100,0 & 114 \\
\hline & & IG & 0 & 0,0 & 4 & 100,0 & 4 \\
\hline & & RPW & 0 & 0,0 & 3 & 100,0 & 3 \\
\hline & & RPOWŚ & 0 & 0,0 & 13 & 100,0 & 13 \\
\hline & & RPOWM & 0 & 0,0 & 1 & 100,0 & 1 \\
\hline & & inne & 1 & 100,0 & 0 & 0,0 & 1 \\
\hline & \multirow{2}{*}{$\begin{array}{c}\text { Zasięg } \\
\text { terytorialny }\end{array}$} & regiony & 12 & 8,8 & 125 & 91,2 & 137 \\
\hline & & kraj & 2 & 11,8 & 15 & 88,2 & 17 \\
\hline \multirow{3}{*}{ 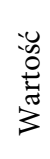 } & Ogółem & mln zł & 21,2 & 4,5 & 447,9 & 95,5 & 469,1 \\
\hline & \multirow{2}{*}{$\begin{array}{l}\text { Wsparcie } \\
\text { UE }\end{array}$} & $\mathrm{mln} \mathrm{zł}$ & 13,4 & 5,1 & 246,7 & 94,9 & 260,0 \\
\hline & & \% ogółem & 63,1 & $\mathrm{X}$ & 55,1 & $\mathrm{X}$ & 55,4 \\
\hline
\end{tabular}

Uwaga: Struktura w podziale na okresy przed i w trakcie istnienia klastra.

Źródło: opracowanie własne na podstawie danych MR (2015)

ogółu), na co złożyły się głównie wszystkie przedsięwzięcia wykonane w ramach PO KL. To samo dotyczyło PO IG i Rozwój Polski Wschodniej (RPW) oraz Regionalnych Programów Operacyjnych Województw (RPOW): świętokrzyskiego i małopolskiego. Poziom przestrzenny w 91,2\% (125) dotyczył projektów wojewódzkich.

Taki stan rzeczy w naturalny sposób bezpośrednio zdeterminował rozkład środków na rozwój województwa w dwóch okresach (tabela 4). W latach 2008-2013 podmioty GTK sfinalizowały 88 ze 100 projektów na rzecz Świętokrzyskiego. Wkład wobec ogółu działań stanowił ok. 63\%, gdyż niektóre podmioty wykazały udział w projektach ogólnokrajowych. 
Tabela 4. Struktura funduszy UE pozyskanych przez podmioty klastra GTK dla rozwoju regionu świętokrzyskiego w latach 2005-2007 i 2008-2013, niezależnie od czasu przystąpienia do klastra

\begin{tabular}{|c|c|c|c|c|c|c|}
\hline \multicolumn{2}{|c|}{ Wyszczególnienie } & $\begin{array}{c}\text { Lata } \\
2005-2007\end{array}$ & $\begin{array}{c}\% \\
\text { ogółu }\end{array}$ & $\begin{array}{c}\text { Lata } \\
2008-2013\end{array}$ & $\begin{array}{c}\% \\
\text { ogółu }\end{array}$ & Ogółem \\
\hline \multicolumn{2}{|c|}{ Liczba podmiotów } & 7 & 26,9 & 23 & 88,5 & 26 \\
\hline \multicolumn{7}{|c|}{ Projekty dla województwa świętokrzyskiego } \\
\hline \multicolumn{2}{|c|}{ Liczba } & 12,0 & 12,0 & 88,0 & 88,0 & 100 \\
\hline \multicolumn{2}{|c|}{$\%$} & 85,7 & $\mathrm{X}$ & 62,9 & $\mathrm{X}$ & 64,9 \\
\hline \multirow{2}{*}{ Wartość } & $\operatorname{mln} \mathrm{zl}$ & 10,4 & 2,7 & 370,7 & 97,3 & 381,1 \\
\hline & \% ogółem & 49,0 & $\mathrm{X}$ & 82,8 & $\mathrm{X}$ & 81,2 \\
\hline \multirow{2}{*}{ Wsparcie UE } & $\operatorname{mln} \mathrm{zl}$ & 6,9 & 3,5 & 191,7 & 96,5 & 198,6 \\
\hline & $\%$ dotacji & 51,7 & $\mathrm{X}$ & 77,7 & $\mathrm{X}$ & 76,4 \\
\hline \multicolumn{7}{|c|}{ Projekty pozostałe } \\
\hline \multicolumn{2}{|c|}{ Liczba } & 2 & 3,7 & 52 & 96,3 & 54 \\
\hline \multicolumn{2}{|c|}{$\%$} & 14,3 & $\mathrm{X}$ & 37,1 & $\mathrm{X}$ & 35,1 \\
\hline \multirow{2}{*}{ Wartość } & $\mathrm{mln} \mathrm{zl}$ & 10,8 & 12,3 & 77,3 & 87,7 & 88,1 \\
\hline & \% ogółem & 51,0 & $\mathrm{X}$ & 17,2 & $\mathrm{X}$ & 18,8 \\
\hline \multirow{2}{*}{ Wsparcie UE } & $\mathrm{mln} \mathrm{zl}$ & 6,4 & 10,5 & 55,0 & 89,5 & 61,4 \\
\hline & $\%$ dotacji & 48,3 & $\mathrm{X}$ & 22,3 & $\mathrm{X}$ & 23,6 \\
\hline
\end{tabular}

Uwaga: Struktura w podziale na okresy przed i w trakcie istnienia klastra.

Źródło: opracowanie własne na podstawie danych MR (2015)

Od 2005 r. do 2007 r. tylko 10,4 mln zł, tj. ok. 50\% łącznej wartości projektów z tego okresu (por. tabela 3) wydano na cele związane z województwem świętokrzyskim, a w kolejnych ramach czasowych 37 razy więcej - 370,7 mln zł (ok. 83\%). W badanej grupie w latach 2005-2013 wpływ na partycypację w kreowaniu rozwoju województwa świętokrzyskiego był bardzo istotny. Taka struktura pozyskiwania nie odbiegała zasadniczo od kształtu dotyczącego całego kraju lub poszczególnych województw (Kiniorska, Pałka, Brambert, 2015).

Interesującym zagadnieniem była kwestia odpowiedzi na pytanie, jak na tle aktywności w pozyskiwaniu funduszy UE przez członków GTK w latach 2005-2013 kształtowała się ich aktywność od momentu członkostwa. Dlatego wyszczególniono charakterystykę funduszy zdobytych przez 26 podmiotów w latach 2007-2013 uzależnioną od daty wejścia do klastra (tabela 5). Z analizy wynika, że beneficjenci, będąc w klastrze, zrealizowali większość swoich projektów - 129, tj. ok. 84\% przedsięwzięć z lat 2005-2013. Wśród nich było głównie 110 (96\%) umów w ramach PO KL. Zasięg przestrzenny na poziomie województw dotyczył 83\% (114) przypadków.

Będąc członkiem klastra, przedsiębiorstwa zrealizowały inwestycje w wysokości 374,2 mln zł, tj. 80\% z kwoty ogółem - 469,1 mln zł - gdzie dotacja UE pokryła połowę kosztów inwestycji (186,5 mln zł) i wyniosła ok. $72 \%$ sumy niezależnej od członkostwa (260,0 mln zł). Struktura funduszy UE z lat 2011-2013 była taka sama jak w przypadku struktury nieuwzględniającej jako kryterium momentu przystąpienia podmiotu do klastra. Od 2010 r. nastąpił bardzo dynamiczny i korzystny czas w odniesieniu do liczby beneficjentów, zawartych umów, szerokiego spektrum programów operacyjnych z dużym poziomem pomocy $\mathrm{z}$ budżetu UE, jak również z ukierunkowaniem na województwa. 
Opisana sytuacja rzutuje na obraz funduszy pozyskanych przez członków klastra dla rozwoju województwa świętokrzyskiego, w zależności od czasu wejścia do GTK (tabela 6). Zrealizowanych zostało wtedy 77 ze 100 projektów, które analogicznie do lat 20052013 miały przeważający udział, oprócz 2013 r. Warto dostrzec, że w 2009 r. miało miejsce przedsięwzięcie związane $\mathrm{z}$ rozwojem infrastruktury Targów Kielce, a jego kwota przewyższała wielokrotnie pozostałe łączne wartości projektów, bowiem wyniosła ona 190 mln zł. Dla porównania: kwota ogółem kosztów projektów wojewódzkich skorelowanych z czasem wejścia do klastra wyniosła ok. $297 \mathrm{mln}$ zł (79\%). Można więc wysunąć wniosek, że zrzeszanie się podmiotów, chętnych do pozyskiwania funduszy UE na rozwój działalności, mogło sprzyjać takiej aktywności.

Przejawem wzrostu aktywności może być liczba członków klastra, którzy dotychczas pozyskiwali fundusze w świetle uwzględnionych podokresów. Stąd 3 przedsiębiorstwa czyniły to tylko w latach 2005-2007. Czterech beneficjentów z pierwszego okresu kontynuowało pozyskiwanie funduszy w drugim przedziale czasu. W latach 2008-2013 takich starań dokonało 19 członków.

Konieczne jest zwrócenie szczególnej uwagi na grupę, która systematycznie przed powstaniem, a głównie w trakcie rozwoju klastra kreowała funduszami europejskimi sytuację społeczno-gospodarczą. Mimo niewielkiej liczby, przedsiębiorstwa łącznie zrealizowały 95 projektów (ok. 62\% wszystkich projektów podmiotów klastra) o wartości 123,7 mln zł, czyli dotyczyły one przeszło $25 \%$ ogółu kosztów. Tymi liderami pod względem liczby projektów były następujące podmioty:

1. „SEKA” Kielce, z branży szkoleniowej (projekty - 44; kwota - 73,4 mln zł),

2. Świętokrzyskie Centrum Innowacji i Transferu Technologii (ŚCITT), z branży doradztwa biznesowego (projekty - 24; kwota - 27,1 mln zł),

3. Stowarzyszenie Integracja i Rozwój (SIR), z branży szkoleniowej (projekty - 20; kwota $15,5 \mathrm{mln} \mathrm{zł})$.

Natomiast liderami wśród podmiotów, które taką aktywność uruchomiły w latach 2008-2013, byli:

1. BCO Biuro Doradztwa Biznesowego, z branży doradztwa biznesowego (projekty - 12; kwota - 5,4 mln zł),

2. „Instytut Innowacji i Biznesu”, z branży doradztwa biznesowego (projekty - 10; kwota $6,5 \mathrm{mln} \mathrm{zl})$,

3. Fundacja Centrum Europy Lokalnej (CEL), z branży szkoleniowej (projekty - 10; kwota $-4,8 \mathrm{mln} \mathrm{zl}$ ),

4. Izba Gospodarcza GTK (projekty - 6; kwota - 14,6 mln zł).

W opracowaniu położono nacisk na analizę środków unijnych na rzecz rozwoju przedsiębiorczości, innowacyjności i konkurencyjności w województwie świętokrzyskim, które zostały zdobyte przez podmioty klastra w latach 2008-2013, niezależnie od czasu przystąpienia (tabela 7). Projekty rozpatrywano w świetle ich tematyki i celów działań obranych w programach operacyjnych. Umożliwiło to pogrupowanie określonych przedsięwzięć na trzy kierunki rozwoju:

- mieszany, tj. z pogranicza działań dla poprawy przedsiębiorczości, innowacyjności i konkurencyjności,

- dla poprawy przedsiębiorczości,

- dla poprawy innowacyjności.

W grupach tych dane usystematyzowano wg wartości projektów i rodzaju programu operacyjnego. 
Tabela 5. Struktura funduszy UE pozyskanych przez podmioty klastra GTK w latach 2007-2013, w zależności od czasu przystąpienia do klastra

\begin{tabular}{|c|c|c|c|c|c|c|c|c|c|c|}
\hline & \multirow{2}{*}{\multicolumn{2}{|c|}{ Wyszczególnienie }} & \multicolumn{7}{|c|}{ Lata } & \multirow{2}{*}{ Ogółem } \\
\hline & & & 2007 & 2008 & 2009 & 2010 & 2011 & 2012 & 2013 & \\
\hline & \multicolumn{2}{|c|}{ Liczba podmiotów } & 2 & 5 & 6 & 11 & 8 & 8 & 6 & 26 \\
\hline \multirow{12}{*}{ 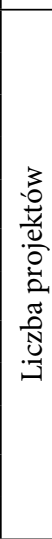 } & \multicolumn{2}{|c|}{ Ogółem } & 2 & 11 & 20 & 25 & 29 & 21 & 21 & 129 \\
\hline & \multirow{2}{*}{$\begin{array}{c}\text { Fundusz } \\
\text { (skrót) }\end{array}$} & EFRR & 2 & 1 & 2 & 7 & 3 & 2 & 2 & 19 \\
\hline & & EFS & 0 & 10 & 18 & 18 & 26 & 19 & 19 & 110 \\
\hline & \multirow{7}{*}{$\begin{array}{l}\text { Program } \\
\text { Operacyjny } \\
\text { (skrót) }\end{array}$} & ZPORR & 1 & 0 & 1 & 0 & 0 & 0 & 0 & 2 \\
\hline & & WKP & 1 & 0 & 0 & 0 & 0 & 0 & 0 & 1 \\
\hline & & KL & 0 & 11 & 17 & 18 & 26 & 19 & 19 & 110 \\
\hline & & IG & 0 & 0 & 0 & 1 & 1 & 1 & 0 & 3 \\
\hline & & RPW & 0 & 0 & 1 & 1 & 0 & 1 & 0 & 3 \\
\hline & & RPOWŚ & 0 & 0 & 1 & 5 & 1 & 0 & 2 & 9 \\
\hline & & RPOWM & 0 & 0 & 0 & 0 & 1 & 0 & 0 & 1 \\
\hline & \multirow{2}{*}{$\begin{array}{c}\text { Zasięg } \\
\text { terytorialny }\end{array}$} & regiony & 2 & 8 & 17 & 24 & 25 & 19 & 19 & 114 \\
\hline & & kraj & 0 & 3 & 3 & 1 & 4 & 2 & 2 & 15 \\
\hline \multirow{4}{*}{ 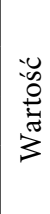 } & Ogółem & $\mathrm{mln} \mathrm{zl}$ & 1,5 & 16,7 & 213,5 & 45,5 & 53,4 & 18,4 & 25,2 & 374,2 \\
\hline & \multirow{3}{*}{$\begin{array}{l}\text { Wsparcie } \\
\text { UE }\end{array}$} & mln $\mathrm{zł}$ & 0,4 & 12,1 & 78,0 & 26,6 & 35,9 & 14,6 & 18,8 & 186,5 \\
\hline & & \% ogółem & 26,7 & 72,6 & 36,5 & 58,6 & 67,3 & 79,3 & 74,7 & 49,9 \\
\hline & & $\begin{array}{l}\text { średni } \\
\text { udział }\end{array}$ & 27,2 & 82,8 & 73,3 & 55,8 & 76,4 & 79,1 & 66,8 & 65,9 \\
\hline
\end{tabular}

Źródło: opracowanie własne na podstawie danych MR (2015)

Tabela 6. Struktura funduszy UE pozyskanych przez członków klastra GTK dla rozwoju regionu świętokrzyskiego w latach 2007-2013, w zależności od czasu przystąpienia do klastra

\begin{tabular}{|c|c|c|c|c|c|c|c|c|c|}
\hline \multirow{2}{*}{\multicolumn{2}{|c|}{ Wyszczególnienie }} & \multicolumn{7}{|c|}{ Lata } & \multirow{2}{*}{ Ogółem } \\
\hline & & 2007 & 2008 & \begin{tabular}{|l|l}
2009 \\
\end{tabular} & 2010 & 2011 & 2012 & \begin{tabular}{|l|l|}
2013 \\
\end{tabular} & \\
\hline \multicolumn{2}{|c|}{ Liczba podmiotów } & 2 & 5 & 6 & 11 & 8 & 8 & 6 & 26 \\
\hline \multicolumn{10}{|c|}{ Projekty dla województwa świętokrzyskiego } \\
\hline \multicolumn{2}{|c|}{ Liczba } & 2 & 7 & 13 & 15 & 18 & 14 & 8 & 77 \\
\hline \multicolumn{2}{|c|}{$\%$} & 100 & 63,6 & 65,0 & 60,0 & 62,1 & 66,7 & 38,1 & 59,7 \\
\hline \multirow{2}{*}{ Wartość } & $\mathrm{mln} \mathrm{zl}$ & 1,5 & 3,2 & 198,8 & 36,3 & 30,1 & 13,6 & 13,4 & 296,9 \\
\hline & \% ogółem & 100,0 & 19,3 & 93,1 & 79,8 & 56,4 & 74,1 & 53,1 & 79,4 \\
\hline \multirow{2}{*}{$\begin{array}{c}\text { Wsparcie } \\
\text { UE }\end{array}$} & $\mathrm{mln} \mathrm{zl}$ & 0,4 & 2,7 & 67,7 & 19,4 & 21,8 & 10,8 & 8,8 & 131,6 \\
\hline & $\%$ dotacji & 100 & 22,6 & 86,7 & 72,6 & 60,6 & 73,9 & 47,0 & 70,5 \\
\hline \multicolumn{10}{|c|}{ Projekty pozostałe } \\
\hline \multicolumn{2}{|c|}{ Liczba } & 0 & 4 & 7 & 10 & 11 & 7 & 13 & 52 \\
\hline \multicolumn{2}{|c|}{$\%$} & 0,0 & 36,4 & 35,0 & 40,0 & 37,9 & 33,3 & 61,9 & 40,3 \\
\hline \multirow{2}{*}{ Wartość } & $\operatorname{mln} \mathrm{zl}$ & 0,0 & 13,5 & 14,7 & 9,2 & 23,3 & 4,8 & 11,8 & 77,3 \\
\hline & \% ogółem & 0,0 & 80,7 & 6,9 & 20,2 & 43,6 & 25,9 & 46,9 & 20,6 \\
\hline \multirow{2}{*}{$\begin{array}{l}\text { Wsparcie } \\
\text { UE }\end{array}$} & $\mathrm{mln} \mathrm{zl}$ & 0,0 & 9,4 & 10,3 & 7,3 & 14,2 & 3,8 & 10,0 & 55,0 \\
\hline & $\%$ dotacji & 0,0 & 77,4 & 13,3 & 27,4 & 39,4 & 26,1 & 53,0 & 29,5 \\
\hline
\end{tabular}

Źródło: opracowanie własne na podstawie danych MR (2015) 
Największą grupę projektów stanowiły te o mieszanym kierunku rozwoju. To zbiór w liczbie 47 realizacji o łącznej wartości 278,7 mln zł. Dotyczyły one 53,4\% przedsięwzięć dla regionu, a 75\% ich kwoty. W tej sferze rozwojowej wykazano 8 rodzajów działań. Zdecydowana większość przypadków (34) wychodziła z realizacji PO KL, zaś z uwagi na kwotę wydatkowania w programie maksimum $(9,2 \mathrm{mln}$ zł) przeznaczone zostało na działania związane $\mathrm{z}$ transferem wiedzy. Kolejne 2 działania koncentrowały się na: wzmocnieniu i rozwoju potencjału dydaktycznego uczelni oraz zwiększeniu liczby absolwentów kierunków o kluczowym znaczeniu dla gospodarki opartej na wiedzy (ok. 9,0 mln zł), a także przeciwdziałaniu wykluczeniu i wzmocnieniu sektora ekonomii społecznej (8,0 mln zł). Jednak główną rolę pod względem pochłoniętych funduszy dla tzw. mieszanego kierunku rozwoju odegrały stricte regionalne programy operacyjne. Chodzi o wspomniany projekt z PO RPW dotyczący rozwoju infrastruktury turystyki kongresowej i targowej. Poza tym były to działania promujące gospodarczo i turystycznie region $(30,2 \mathrm{mln}$ zł) i wspierające bezpośrednio sektor mikro-, małych i średnich przedsiębiorstw (27,6 mln zł) w ramach RPOWŚ.

W kierunku rozwoju regionalnej przedsiębiorczości miało miejsce tylko 17 realizacji (19\% ogółu), opiewających na kwotę 19,0 mln zł (5\%). Wszystkie 4 działania dotyczyły PO KL. Dwa wiodące miały za zadanie podniesienie atrakcyjności i jakości szkolnictwa zawodowego (ok. 8,0 mln zł), a także wspieranie przedsiębiorczości i samozatrudnienia $(6,6 \mathrm{mln} \mathrm{zl})$.

Niestety, ukierunkowanie bezpośrednio na innowacyjność było najsłabsze. Odnosiło się do tego celu $10 \%$ projektów regionalnych (9 umów), a środki na niego przeznaczone nie przekroczyły nawet $2 \%(7,1 \mathrm{mln}$ zł). W tym obszarze aktywności członków klastra najwięcej wydano $(5,3 \mathrm{mln}$ zl) na trzykrotne wdrożenie elektronicznego biznesu B2B, $\mathrm{w}$ ramach PO IG.

Przedsiębiorstwa klastra GTK dostrzegały rolę sieci współpracy w kreowaniu innowacyjności regionalnej, co ujawniło się w podejmowaniu działań mieszczących się w zakresie problemów Regionalnej Strategii Innowacji i Transferu Wiedzy, Zintegrowanego Programu Operacyjnego Rozwoju Regionalnego (ZPORR). Sieci współpracy były istotnym powodem sięgania po środki pomocowe, przez co stały się ważną składową rozwoju obszarów, co potwierdza polityka spójności i polaryzacyjno-dyfuzyjny model rozwoju. Jeden z takich projektów (0,3 mln zł) zrealizowała w 2009 r. Izba Gospodarcza GTK, a zmierzał on do rozwoju sieci współpracy i wymiany innowacji w klastrze. Z kolei 3 tego typu przedsięwzięcia, o łącznej kwocie $0,9 \mathrm{mln}$ zł, zostały zrealizowane przez ŚCITT. Były to projekty:

- „Centrum Nordyckie”,

- „Regionalne centrum naukowo-technologiczne jako platforma kreowania innowacji”,

- „Tworzenie i rozwój sieci współpracy służącej transferowi know-how poprzez promocję i upowszechnianie dobrych praktyk w zakresie Odnawialnych Źródeł Energii OZE Świętokrzyskie”.

Nie były to jedyne działania członków klastra w badanym zakresie. Kolejny przejaw stanowiły projekty partnerskie w klastrze i poza nim. Współpracę podmiotów klastra wg funduszy UE w latach 2008-2013 przedstawia tabela 8. Skoncentrowano się na realizacjach, których tematyka i cele wdrażały praktyczne przejawy przedsiębiorczości (np. własna działalność gospodarcza), innowacyjności (np. nowy produkt/ usługa) lub konkurencyjności. Nie wzięto pod uwagę projektów przeznaczonych wyłącznie dla poprawy wiedzy, umiejętności i kompetencji. 


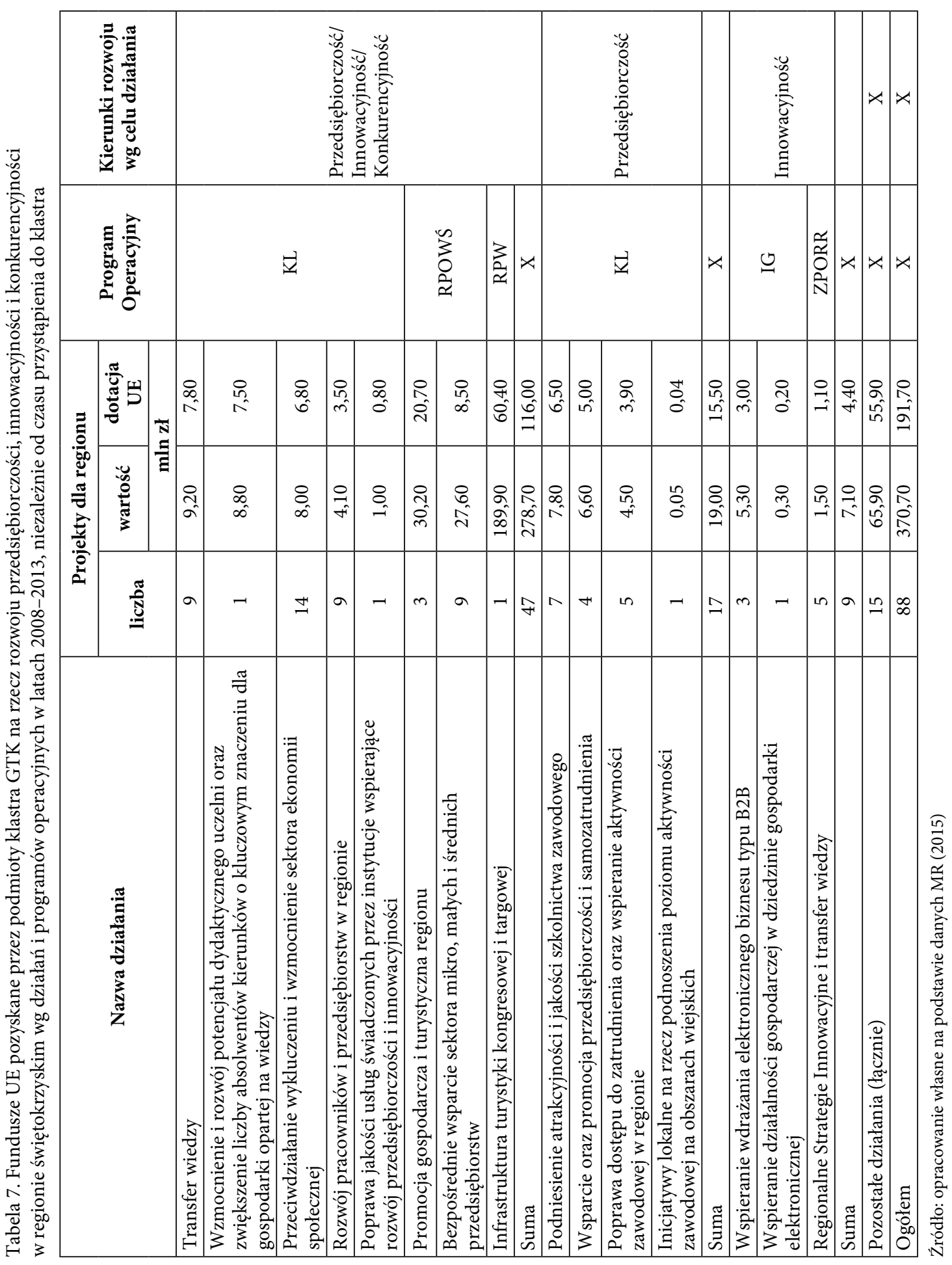


Zestawienie odzwierciedla specyfikę polityki klastrowej dla rozwoju regionalnego. Zrealizowano 6 przedsięwzięć w ogólnej kwocie 42,1 mln zł. Źródłem dotacji większości z nich był EFRR, w tym dla połowy przypadków - WPO. W strukturze partnerstw było 4 liderów należących do klastra, z czego liderem 3 projektów była Izba Gospodarcza GTK. Kooperantami były 4 przedsiębiorstwa klastra, a 3 podmioty nie były zrzeszone. Zgodnie $\mathrm{z}$ wydzielonymi 3 aspektami rozwoju stwierdzono rangę współpracy sieciowej w ukierunkowaniu wzrostu. Była ona najbardziej istotna w przypadku tzw. mieszanego kierunku rozwoju. Złożyły się na to praktycznie wszystkie wyróżnione projekty partnerskie, wśród nich te, w których liderem był koordynator GTK.

Skoncentrowano się na wspólnej promocji gospodarczej i turystycznej województwa (3 projekty o łącznej wartości 30,2 mln zł). Znaczący przykład to rewitalizacja i wytyczenie szlaku architektury drewnianej oraz średniowiecznej w regionie świętokrzyskim o wartości ok. 18,0 mln zł. Pojedyncze działanie dotyczyło: wzrostu stopnia powiązania oferty kształcenia Uniwersytetu Jana Kochanowskiego w Kielcach (UJK) z rzeczywistymi potrzebami rynku pracy, poprawy jakości procesu dydaktycznego oraz wzmocnienia potencjału instytucjonalnego uczelni, zgodnie z wymaganiami gospodarki opartej na wiedzy, przy merytorycznym i praktycznym zaangażowaniu przedsiębiorców z klastra $(8,8 \mathrm{mln} \mathrm{zł})$. Kolejne odnosiło się do stworzenia inkubatora przedsiębiorczości dla młodzieży, aby wykształcić i wesprzeć właściwe postawy w kierunku podejmowania własnej działalności gospodarczej (1,0 mln zł). Innowacyjny kierunek rozwoju spełniony został tylko przez jeden projekt partnerski, dotyczący stworzenia cyfrowej platformy wymiany informacji i wiedzy między podmiotami (2,2 mln zł).

Konkurencja na rynku lokalnym, regionalnym, krajowym czy wspólnotowym wymusza większą elastyczność działania, szybsze sposoby pozyskiwania informacji, a jednocześnie wykorzystanie procesu konsultacji z partnerami. Wiele przedsiębiorstw, w tym głównie małych i średnich, poszukuje rozwiązania problemów z utrzymaniem działalności, wykorzystując wiedzę, doświadczenie lub niektóre zasoby pozyskane od partnerów działających w ramach sieci. Współpracę sieciową wyróżnia układ zachodzących relacji, gdzie każda organizacja kooperująca z pozostałymi jest równorzędnym partnerem z punktu widzenia liczby tworzonych relacji i pozycji organizacji w danej sieci. Dzieje się to także na płaszczyźnie starania się o środki unijne przez podmioty współpracujące w klastrze.

$\mathrm{Z}$ tego względu w badaniu sporządzona została mapa sieci współpracy podmiotów klastra (rycina 1), która pozwala skupić uwagę na strukturze relacji, w skład których dany podmiot jest włączony. Wszystkie strony współpracy zlokalizowane zostały w Kielcach, z wyjątkiem spółki Fama-Bruk (gmina Pawłów). Koordynator klastra rozwinął największą sieć współpracy z dwoma podmiotami z klastra, aktywnymi w kwestiach rozwoju społeczno-gospodarczego (CEL, SIR), a także dwiema instytucjami edukacyjnymi spoza klastra - UJK i Świętokrzyskim Centrum Doskonalenia Nauczycieli (ŚCDN). To pod względem siły druga sieć współpracy, w której najsilniejsza relacja nastąpiła wobec UJK. Jest to wyraźne potwierdzenie realizowania koncepcji klastra, który nie może obyć się bez współpracy z instytucjami ze sfery nauki, czy przygotowującymi odpowiednio wykształcone kadry potencjalnych pracowników regionalnych organizacji. Stowarzyszenie „ARS SACRA”, działające w klastrze na rzecz turystyki, wraz z Biurem Polityki Gospodarczej i Rozwoju Regionalnego EPRD zawiązały najwyższy poziom współpracy. Biuro EPRD było jednocześnie liderem przedsięwzięcia z PO IG, wspólnie ze stowarzyszeniem SIR oraz spółką Fama-Bruk. 
Znaczenie funduszy unijnych dla rozwoju przedsiębiorczości i innowacyjności...

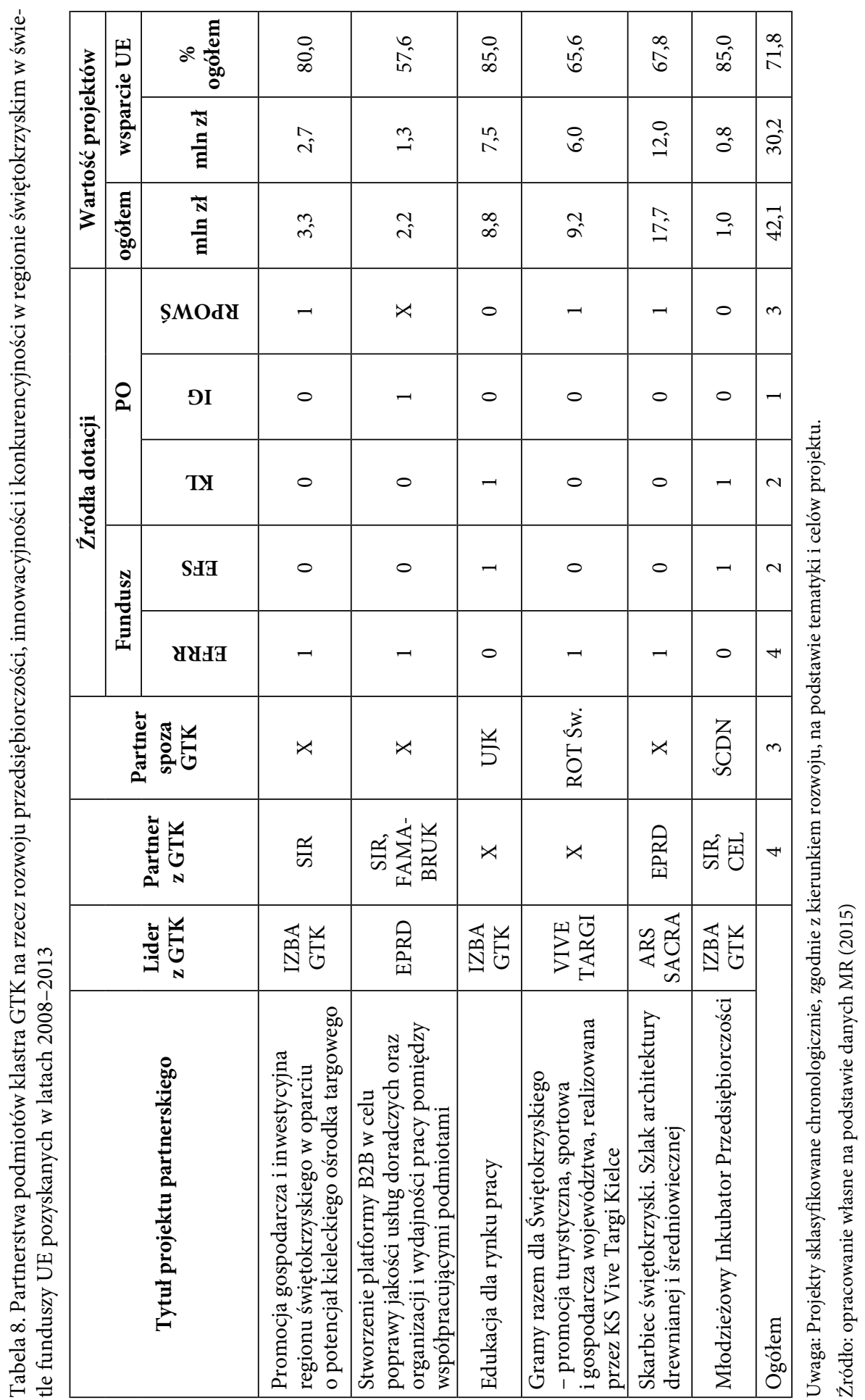


Rycina 1. Mapa sieci współpracy podmiotów klastra GTK wg projektów partnerskich i wartości funduszy UE pozyskanych w latach 2008-2013

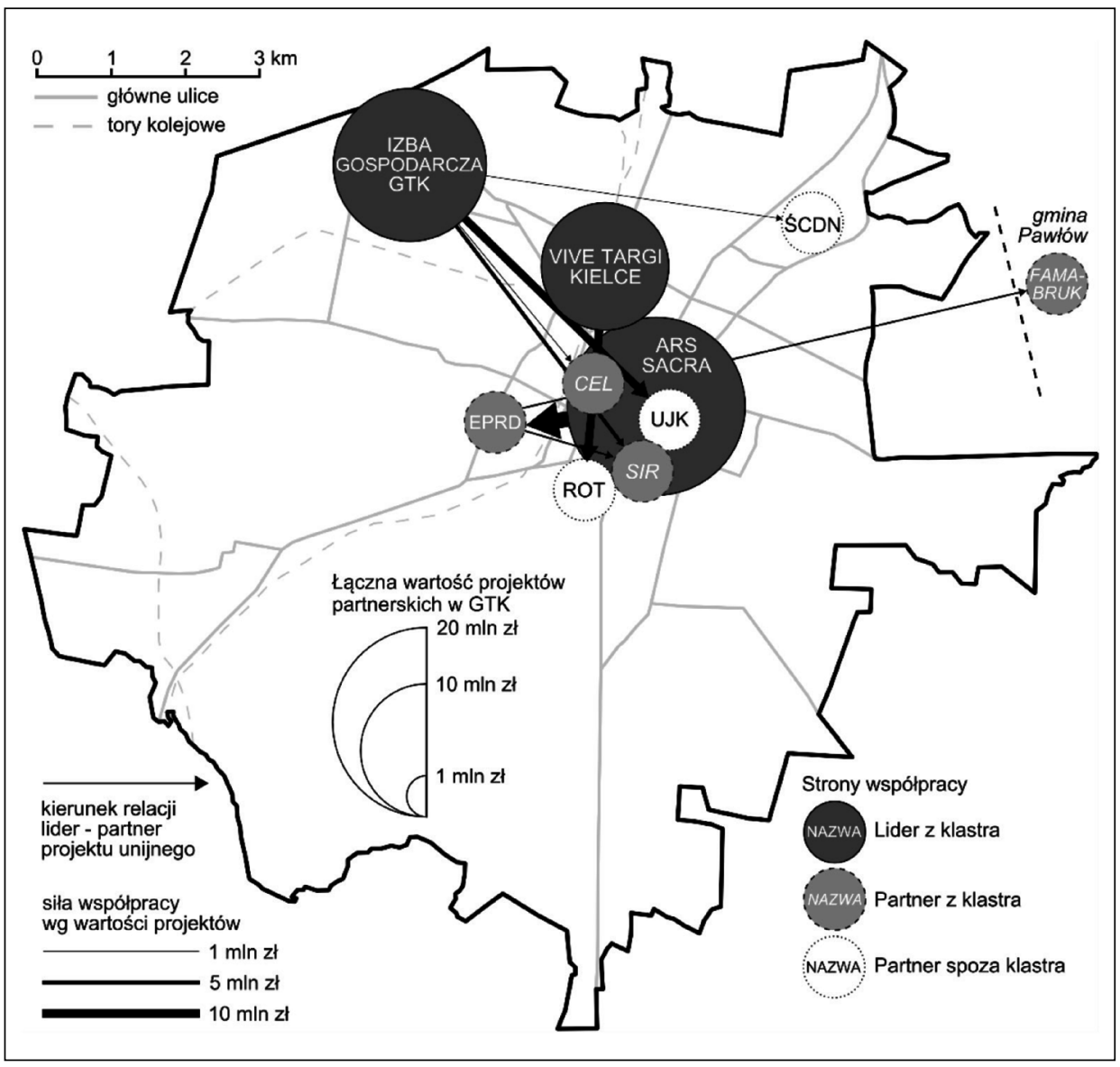

Źródło: opracowanie własne

Zwracając uwagę na samodzielną aktywność klastra GTK na rzecz rozwoju województwa świętokrzyskiego - gdy beneficjentem w imieniu zrzeszenia był koordynator stwierdzono, że największy nacisk położono na wspomniane już wzmocnienie i wzrost potencjału dydaktycznego kieleckiego uniwersytetu. Projekt „Edukacja dla rynku pracy” (PO KL) stanowił 60\% funduszy pozyskanych przez izbę gospodarczą. Prawie $25 \%$ możliwości klaster wykorzystał na promocję gospodarczą i inwestycyjną regionu, na fundamencie ośrodka targowego (RPOWŚ). Indywidualne wnioski projektowe klastra ukierunkowane na transfer wiedzy zaabsorbowały łącznie 10\% wartości, a ściśle wiązały się z rozwojem przedsiębiorczości i innowacyjności. Były to trzy projekty: „Akademicki Inkubator Przedsiębiorczości” oraz „Przedsiębiorczy Student” (PO KL), „Rozwój sieci współpracy i wymiany innowacji w klastrze Grono Targowe Kielce” (ZPORR). Klaster zaabsorbował 14,6 mln zł z otrzymanym wkładem ze strony UE lub budżetu państwa w wysokości 12,2 mln (ok. 84\%). Proporcje te dowodzą o istocie działalności klastra w rozwoju regionalnym z punktu widzenia osi rozwoju UE. 
Wnioski

Strukturę sieci współpracy w obliczu rywalizacji o fundusze UE budują przede wszystkim podmioty klastra GTK z siedzibą w przestrzeni lokalnej, ale czynne w działaniach na rzecz różnych aspektów rozwoju regionalnego (m.in. edukacji, rynku pracy, gospodarki, innowacji, turystyki i rekreacji). Klaster sprzyja działaniom dostosowanym do bieżącej sytuacji rynkowej. Dzięki współpracy w sieci wypracowane efekty zewnętrzne mogą rozchodzić się na inne działalności oraz do innych obszarów.

Badania wykazały, że pozyskiwane przez klaster i jego członków fundusze unijne przyczyniają się do wzrostu przedsiębiorczości, innowacyjności i konkurencyjności województwa świętokrzyskiego. Beneficjenci, będąc w klastrze, wykonali zdecydowaną większość projektów. Dotyczyły one głównie kapitału ludzkiego. Zasięg przestrzenny na poziomie województw zdominował strukturę liczebną na korzyść Świętokrzyskiego, zwłaszcza pod względem wysokości zaabsorbowanych środków. Cele tych projektów dotyczyły trzech kierunków, spośród których najważniejszą grupę stanowił szeroko rozumiany kierunek poprawy konkurencyjności regionu. W jego zakres weszły trzy najdroższe projekty: poprawy infrastruktury kongresowej i targowej, promocji gospodarczej i turystycznej regionu oraz wsparcia sektora MSP. Na drugim miejscu były realizacje wzmacniające przedsiębiorczość. Samo GTK skupiło się przede wszystkim na wsparciu potencjału dydaktycznego ośrodka akademickiego na rzecz potrzeb rynku pracy, a także na promocji gospodarczej i inwestycyjnej regionu. W dodatku kształtowanie sieci współpracy było istotną przyczyną pozyskiwania środków rzutujących na rozwój obszaru.

Oceniając stopień wpływu specjalizacji branżowej przedsiębiorstw na wielkość pozyskiwanych środków unijnych, stwierdzono istnienie kilku bardzo silnych jednostek o potencjale doradczo-finansowym lub szkoleniowym, które były liderami klastra w kreowaniu funduszami europejskimi sytuacji społeczno-gospodarczej województwa świętokrzyskiego. Należą one równocześnie do rdzenia klastra, ponieważ działają aktywnie na rzecz współpracy w klastrze oraz wzrostu jego specjalizacji.

Specjalności klastra są cenne dla aktywizacji społeczno-gospodarczej przestrzeni lokalnej i regionalnej tym bardziej, że w województwie, z wyjątkiem Kielc, panuje duży niedobór koncentracji usług wyższego rzędu. Najwięcej podmiotów klastra świadczy usługi, które wg poziomów intensywności B+R określane są jako usługi oparte na wiedzy i usługi wysokiej techniki. Członkowie klastra tworzą węzły nowoczesnej sieci współpracy, która koncentruje się na wzroście branży targowo-wystawienniczej i kongresowej w województwie świętokrzyskim, scalonej z rozwojem gospodarki opartej na wiedzy.

Rozpatrywany przykład aktywności gospodarczej może być elementem poprawiającym poziom rozwoju społeczno-gospodarczego $\mathrm{w}$ tzw. regionach zagrożonych peryferyzacją. Do takiego obszaru należy województwo świętokrzyskie, które wymaga przełamania negatywnych trendów. W regionie zatem muszą być podejmowane głównie takie działania, jak: wzmacnianie liderów regionalnej innowacyjności, kreowanie sieci powiązań między przedsiębiorstwami dla transferu nowych technologii i rozwoju innowacji, ograniczanie barier wdrażania innowacji. Efektywność tych działań uzależniona jest od finansowego wsparcia, które w zdecydowanej mierze pochodzi z budżetu UE. Badania autorów potwierdziły wyniki wcześniejszych opracowań, dotyczących zwiększenia środków na przedsiębiorczość i innowacyjność regionu, ale nie można jeszcze stwierdzić, czy przekłada się to na zmniejszenie dystansu rozwojowego względem pozostałych obszarów Polski. 
Należy zauważyć, że pomimo licznych prac nad problematyką partnerstwa przedsiębiorstw, ich innowacyjności i konkurencyjności, nie udało się dotąd stworzyć optymalnych metod badawczych pozwalających na szczegółową analizę danych ilościowych. Deficyt ten jest zauważalny zarówno w odniesieniu do współpracy sieciowej w ujęciu osobowym, jak i w ujęciu gospodarczym, czyli w rozróżnieniu na podmioty relacji. Analiza relacji może sprowadzać się do opisu liczebności kontaktów z innymi członkami sieci albo obejmować rodzaj tych relacji i implikacji wynikających dla każdej ze stron. Zaprezentowane podejście może stanowić podstawę do dalszych badań w tym zakresie, rozszerzając zasięg analizy o wymiar regionalny i ponadregionalny, z uwzględnieniem zmian w czasie. W ujęciu teoretycznym ciekawym nurtem mogą okazać się badania porównawcze między klastrami z różnych branż i o odmiennej specyfice, w celu sformułowania praw determinujących procesy przedsiębiorczości i innowacyjności.

Wypracowane wyniki analiz mogą być cennym źródłem informacji dla członków klastra. Ukazanie znaczenia powiązań sieciowych na płaszczyźnie funduszy UE może przełożyć się na większą efektywność w podejmowanych działaniach. Wnioski mogą posłużyć do opracowania strategii zmierzających do wzrostu konkurencyjności.

Realną jednak barierą jest dostępność danych, które są niechętnie udostępniane przez przedsiębiorców, co znacznie ogranicza możliwości analityczne w aspekcie teoretycznym i praktycznym.

\section{Literatura}

References

Altuntas, S., Dereli, T., Kusiak, A. (2016). Assessment of corporate innovation capability with a data-mining approach: industrial case studies. Computers \& Industrial Engineering, 102, 58-68.

Alves, A.C., Barbieux, D., Reichert, F.M., Tello-Gamarra, J., Zawislak, P.A. (2017). Innovation and dynamic capabilities of the firm: definining an assessment model. RAE-Revista de Administração de Empresas, 57(3), 232-244.

Anderson, P., Tushman, M.L. (1990). Technological Discontinuities and Dominant Design: A Cyclical Model of Technological Change. Administrative Science Quarterly, 35(4), 604-633.

Bojar, E. (red.). (2006). Klastry jako narzędzia lokalnego i regionalnego rozwoju gospodarczego. Lublin: Wydawnictwo Politechniki Lubelskiej.

Brambert, P. (2016). Wplyw wspótpracy sieciowej na przedsiębiorczość i innowacyjność w regionie świętokrzyskim na przykładzie klastra Grono Targowe Kielce. Praca doktorska. Kielce: Uniwersytet Jana Kochanowskiego.

Brambert, P. (2018). Kondycja ekonomiczna członków klastra Grono Targowe Kielce. „Stare i nowe” problemy badawcze w geografii społeczno-ekonomicznej, 8, 139-149.

Brdulak, J., Kulikowski, M. (red.). (2004). Przedsiębiorczość stymulatorem rozwoju gospodarczego. Warszawa: Instytut Wiedzy SGH.

Breschi, S., Malerba, F. (2007). Clusters, Networks and Innovation. Oxford: Oxford University Press.

Brodzicki, T., Kuczewska, J. (red.). (2012). Klastry i polityka klastrowa w Polsce: konkurencyjność przedsiębiorstw, sektorów i regionów. Gdańsk: Wydawnictwo Uniwersytetu Gdańskiego.

Churski, P. (red.). (2014). Rozwój społeczno-gospodarczy a kształtowanie się obszarów wzrostu i obszarów stagnacji gospodarczej. Rozwój Regionalny i Polityka Regionalna nr 25.

Delgado, M., Ketels, C., Porter, M.E., Stern, S. (2012). The Determinants of National Competitiveness. NBER Working Paper No. 18249. Pozyskano z: https://doi.org/10.3386/w18249

Enright, M.J. (1996). Regional Clusters and Economic Development: A Research Agenda. W: U. Staber, N. Schaefer, B. Sharma (red.), Business Networks: Prospects for Regional Development. Berlin: Walter de Gruyter, 190-213. 
Felin, T., Powell, T.C. (2016). Designing Organizations for Dynamic Capabilities. California Management Review, 58(4), 78-96.

Jaki, A., Rojek, T. (2018). Rola funduszy europejskich w kreowaniu rozwoju i innowacyjności regionów w Polsce. Studia i Prace WNEIZ US, 52/2, 53-70.

Jasińska-Biliczak, A. (2017). Endogeniczne uwarunkowania innowacyjności sektora małych i średnich przedsiębiorstw w regionie - ujęcie teoretyczne i praktyczne. Studia KPZK PAN, CLXXXI. Warszawa: KPZK PAN.

Kamińska, W. (2006). Pozarolnicza indywidualna działalność gospodarcza w Polsce w latach 1988-2003. Prace Geograficzne, 203.

Kamińska, W., Heffner, K. (red.). (2010). Kapitał ludzki i społeczny w procesie rozwoju obszarów wiejskich. Studia KPZK PAN, CXXVI. Warszawa: KPZK PAN.

Kiniorska, I., Pałka, E., Brambert, P. (2015). Zróżnicowanie społeczno-gospodarcze Polski w kontekście polityki spójności. Studia i Materiały. Miscellanea Oeconomicae, 4, 11-24.

Kline, S.J. (1985). Innovation is not a Linear Proces. Research Management, 28(4), 36-45.

Kowalski, A.M. (2013). Znaczenie klastrów dla innowacyjności gospodarki w Polsce. Warszawa: Oficyna Wydawnicza SGH.

Kuciński, K. (red.). (1999). Lokalne uwarunkowania przedsiębiorczości. Monografie i Opracowania, 499.

Matusiak, K.B. (red.). (2011). Innowacje i transfer technologii. Stownik pojęć. Warszawa: PARP.

Micek, G. (2008). Grona przedsiębiorczości jako przedmiot analizy oraz instrument rozwoju lokalnego i regionalnego w warunkach polskich. Przegląd Geograficzny, 80(4), 541-560.

Ministerstwo Rozwoju (2015, 1-31 maja). Mapa dotacji Unii Europejskiej. Pozyskano z: http://www. mapadotacji.gov.pl

Ministerstwo Rozwoju (2015, 1-31 maja). Portal Funduszy Europejskich na lata 2007-2013. Pozyskano z: https://www.funduszeeuropejskie.2007-2013.gov.pl

Nowak, E., Brambert, P. (2014). Klaster Grono Targowe Kielce jako stymulator rozwoju regionu świętokrzyskiego. Rozprawy Naukowe Instytutu Geografii i Rozwoju Regionalnego Uniwersytetu Wrocławskiego, 33(2), 195-207.

OECD (1997). National Innovation Systems. Paris: OECD Publications. Pozyskano z: https://www.oecd. org/science/inno/2101733.pdf

Olejniczak, K., Dziemianowicz, W. (2003). Global Challenge and Clusters as Local Response - Does it Work in Warsaw? W: A. Kukliński, B. Skuza (red.), Europe in the perspective of Global Change. Warszawa: Oficyna Wydawnicza „Rewasz”, Polish Association for the Club of Rome, 367-385.

Olesiński, Z. (2008). Strategia rozwoju klastrów w województwie świętokrzyskim. Kielce: Centrum Rozwoju Klastrów Świętokrzyskich, Świętokrzyska Agencja Rozwoju Regionalnego.

PARP (2016). Raport $z$ inwentaryzacji klastrów w Polsce 2015. Warszawa: PARP. Pozyskano z: https:// www.pi.gov.pl/parp/chapter_96018.asp

Piątkowski, M.J. (2010). Rola funduszy europejskich w rozwoju przedsiębiorstw innowacyjnych. Zeszyty Naukowe Politechniki Rzeszowskiej - Zarządzanie i Marketing, 17, 577-586.

Płaziak, M., Rachwał, T. (2015). „Przedsiębiorczy region” - zarys koncepcji w świetle analizy roli przedsiębiorczości w krajowej strategii rozwoju regionalnego. Przedsiębiorczość - Edukacja, 11, 37-49.

Porter, M.E. (2000). Location, Clusters, and Company Strategy. W: G. Clark, M. Feldman, M. Gertler, D. Wójcik (red.), The Oxford Handbook of Economic Geography. Oxford: Oxford University Press, 253-274.

Ramanathan, R., Ramanathan, U., Bentley, Y. (2018). The debate on flexibility of environmental regulations, innovation capabilities and financial performance - A novel use of DEA. Omega, 75, 131-138.

Ross, S. (1973). The Economic Theory of Agency: The Principal's Problem. American Economic Review, 63(2), 134-139.

Schumpeter, J.A. (1960). Teoria rozwoju gospodarczego. Warszawa: Wydawnictwo Naukowe PWN.

Stawasz, E. (2013). Innovation capacity of enterprises - selected issues. Acta Universitatis Lodziensis, $277,107-121$. 
Szultka, S. (red.). (2004). Klastry - innowacyjne wyzwanie dla Polski. Gdańsk: Instytut Badań nad Gospodarką Rynkową.

Urząd Miasta Kielce. (2015). Strategia Rozwoju Miasta Kielce na lata 2007-2020. Aktualizacja. Kielce. Pozyskano z: http://www.um.kielce.pl/gfx/kielce2/userfiles/files/pliki/strategia-rozwoju-miasta-kielce-aktualizacja-15092016.pdf

Varis, M., Littunen, H. (2010). Types of innovation, sources of information and performance in entrepreneurial SMEs. European Journal of Innovation Management, 13(2), 128-154.

Zarząd Województwa Świętokrzyskiego. (2014). Strategia Badań i Innowacyjności (RIS3). Od absorpcji do rezultatów - jak pobudzić potencjał województwa świętokrzyskiego 2014-2020+. Kielce: Urząd Marszałkowski Województwa Świętokrzyskiego. Pozyskano z: https://bip.sejmik.kielce.pl/144biuro-innowacji

Zastempowski, M. (2019). Innowacyjność małego przedsiębiorstwa. Toruń: Wydawnictwo Naukowe UMK.

Zioło, Z. (2016). Przedsiębiorczość w rozwoju układów lokalnych. Przedsiębiorczość - Edukacja, 12, 6-17.

Patryk Brambert, dr, adiunkt w Instytucie Geografii i Nauk o Środowiskui Uniwersytetu Jana Kochanowskiego w Kielcach. Doktor nauk o Ziemi w dyscyplinie geografia. Zainteresowania badawcze autora dotyczą: zjawiska klastrów, oceny potencjału przedsiębiorczości i atrakcyjności gospodarczej obszarów oraz specjalizacji gospodarki, konkurencyjności, rozwoju lokalnego i regionalnego.

Patryk Brambert, $\mathrm{PhD}$, assistant professor in the Institute of Geography and Environmental Sciences of the Jan Kochanowski University in Kielce. PhD of Earth sciences in Geography. His research interests concern: the phenomenon of clusters, valorisation of areas in terms of entrepreneurship potential and economic attractiveness, specialisation of the economy, competitiveness, local and regional development.

ORCID: 0000-000-5320-5657

\section{Adres/Address:}

Uniwersytet Jana Kochanowskiego

Wydział Nauk Ścisłych i Przyrodniczych

Instytut Geografii i Nauk o Środowisku

ul. Uniwersytecka 7

25-406 Kielce, Polska

e-mail: patryk.brambert@ujk.edu.pl

Iwona Kiniorska, dr, adiunkt w Instytucie Geografii i Nauk o Środowisku Uniwersytetu Jana Kochanowskiego w Kielcach. Doktor nauk o Ziemi w dyscyplinie geografia. Zainteresowania badawcze autorki skupiają się wokół tematów: obszary zurbanizowane i wiejskie (warunki, poziom i jakość życia, nierówności społeczne) oraz przedsiębiorczość, turystyka wiejska i rozwój lokalny.

Iwona Kiniorska, PhD, assistant professor in the Institute of Geography and Environmental Sciences of the Jan Kochanowski University in Kielce. PhD of Earth sciences in Geography. Her research interests focus on: urbanised and rural areas (conditions, living standards, quality of living, social inequalities) and entrepreneurship, tourism in rural areas and local development.

ORCID: 0000-0001-5630-4554

\section{Adres/Address:}

Uniwersytet Jana Kochanowskiego

Wydział Nauk Ścisłych i Przyrodniczych

Instytut Geografii i Nauk o Środowisku

ul. Uniwersytecka 7

25-406 Kielce, Polska

e-mail: iwona.kiniorska@ujk.edu.pl 